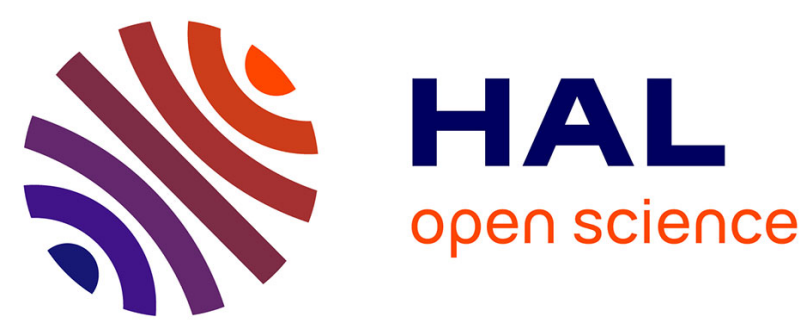

\title{
Customer is King? A Framework to Shift from Cost- to Value-Based Pricing in Software as a Service: The Case of Business Intelligence Software
}

\author{
Aaron W. Baur, Antony C. Genova, Julian Bühler, Markus Bick
}

\section{To cite this version:}

Aaron W. Baur, Antony C. Genova, Julian Bühler, Markus Bick. Customer is King? A Framework to Shift from Cost- to Value-Based Pricing in Software as a Service: The Case of Business Intelligence Software. 13th Conference on e-Business, e-Services and e-Society (I3E), Nov 2014, Sanya, China. pp.1-13, 10.1007/978-3-662-45526-5_1 . hal-01342123

HAL Id: hal-01342123

https://hal.inria.fr/hal-01342123

Submitted on 5 Jul 2016

HAL is a multi-disciplinary open access archive for the deposit and dissemination of scientific research documents, whether they are published or not. The documents may come from teaching and research institutions in France or abroad, or from public or private research centers.
L'archive ouverte pluridisciplinaire HAL, est destinée au dépôt et à la diffusion de documents scientifiques de niveau recherche, publiés ou non, émanant des établissements d'enseignement et de recherche français ou étrangers, des laboratoires publics ou privés. 


\title{
Customer is King? A Framework to Shift from Cost- to Value-Based Pricing in Software as a Service: The Case of Business Intelligence Software.
}

\author{
Aaron W. Baurø, Antony C. Genova, Julian Bühler, Markus Bick \\ Department of Business Information Systems, \\ ESCP Europe Business School Berlin, Germany \\ \{abaur, agenova, jbuehler, mbick\}@escpeurope.eu
}

\begin{abstract}
With a shift from the purchase of a product to the delivery of a service, cloud computing has revolutionized the software industry. Its cost structure has changed with the introduction of Software as a Service (SaaS), resulting in decreasing variable costs and necessary amendments to the software vendors' pricing models. In order to justify the gap between the software's price and the incremental cost of adding a new customer, it is essential for the vendor to focus on the added value for the client. This shift from cost- to valuebased pricing models has so far not been thoroughly studied. Through literature review and expert interviews, a conceptual model for customer-centric SaaS pricing, especially Business Intelligence \& Business Analytics tools, has been developed. The model has then been initially validated by discussions with the top five software players in this realm and builds a strong basis for further theoretical inquiry and practical application.
\end{abstract}

Keywords: Software; Pricing; Business Intelligence; Cloud Computing; SaaS; E-Business Models.

\section{Introduction}

One distinct iconoclasm of Jason Maynard, analyst at Credit Suisse, precisely describes the revolution that has happened in the software industry in the last several years: "Traditional software is dead" [1]. Cloud computing, virtualization and Software as a Service (SaaS) switch the delivery of software from physical distribution and installation on local hardware to a provision over the internet. While a complete virtualization is unlikely, the future of computing will lay in a level state: A harmony between the different extremes of pure on-premise and pure over-thecloud delivery [2].

SaaS delivery ignited the gradual estrangement from perpetual licenses, with a traditional focus on a large sales force, up-front payments, physical product delivery and a frequent and tedious updating process. Now, vendors can update their products 'on-the fly', receive a steady stream of revenue, and focus on a closer client relationship and greater penetration within the client's organizations [3].

These technological and business model changes also largely influence how vendors can set and communicate their pricing policy. Due to the decreased variable 
costs of vendors, there is a gap between the software's price and the incremental costs of adding a new customer. This misalignment is perceived as unfair and therefore criticized by customers, as studies show [4]. Customers are highly sensitive to the pricing techniques used by vendors, and ironically, it is through the pricing strategies themselves that the company can avoid the customer to focus only on the price as a choice parameter [5]. That's why understanding the client is a key characteristic, as the pricing should be designed upon the variables that the buyer will use in measuring value realization [6]. This is what the customer is willing to pay based on the actual benefit. The result should be a win-win scenario, where customers see the value of the software reflected in their business processes and the vendors benefit from recurring payments [3].

Consequently, choosing the right pricing model is of great importance for software vendors as to attract and retain customers and keep competitors at bay. In order to justify such a 'cost-price gap' and to focus on the added value for the customer, pricing models are now increasingly taking into consideration a customer-centric mind set, by associating price perceptions to product configurations [7].

Analyzing the real value the software represents for the customer needs to be in the center of thought. Hence, the price of the software must be aligned to the customer's value realization, i.e. the shift from cost-based software pricing to a more dynamic value-based software pricing [8]. In the latter case, the price is continuously adapted to the market and it is demand driven, based on a deep knowledge of the customers [9].

Numerous studies attempt to analyze pricing techniques in the SaaS age (e.g. $[10,11,12]$. However, there has not yet been an analysis of pricing techniques and their correlation with customer value realization specifically applied to Business Intelligence \& Business Analytics (BI\&BA) solutions for companies. BI\&BA tools may be the keys to dealing with today's data glut and customers pose huge expectations in the performance and quality of these software suites [13]. They are of pivotal importance in the management of a company, and it is the software for which the virtualization process has been among the most challenging due to the complexity of the tools [14]. Additionally, it is an area of the software industry with fierce competition and therefore necessitates a customer-centric approach; their pricing models thus present an ideal object of study.

Hence, the focus of this paper is on the effects of this radical change on the software supplier's business model and the resulting customer relationship. This serves to reduce the identified research gap of a missing application of value-based pricing on BI\&BA tools. This paper studies the available literature in this field and, together with semi-structured interviews, develops a conceptual model of customercentric SaaS BI\&BA pricing as a research result.

The remainder of this paper is structured as follows: Chapter two presents the research methodology applied, while chapter three introduces common pricing concepts of software products in light of the shift from cost- to value- based pricing. Chapter four shortly presents the BI\&BA industry and the five biggest vendors. Results \& implications of the research, i.e. findings in regard to software pricing concepts and a customer-centric framework are then presented in chapter five. Finally, we give a conclusion about a new value proposition applicable to the B2B software industry and sum up the paper in chapter six. 


\section{Theoretical Background}

\subsection{Pricing of Software Products}

As Patrick Heffron ([10], p. 3) puts it, "understanding software pricing is challenging even for the most savvy business people and seasoned technology veterans". Therefore, we will give a short overview of software pricing determinants and dynamics in this chapter.

In a holistic and general view, pricing depends on three important variables, namely costs, customer and competition, which in literature have been referred to as the Three Cs of Pricing [15]. First, the cost structure of software vendors has changed with the advent of SaaS [16]. In contrary to traditional economic theory, where prices were set on the measurement of "replications", i.e. based on the incremental cost of each additional product [17], such a theory has been put into question within the software industry. Here, replication costs of each additional software license sold are practically inexistent [18]. For example, the hosting, management and recovery of systems (including a 99.9\% availability) now take up a much higher percentage of costs than physical reproduction and distribution or customization to different hardware specifications of clients. Expenses are amortized once the number of users grows, which explains the initial difficulty of SaaS providers to achieve profitability [19]. Second, the customers' perception of a price constitutes the top ceiling, above which the vendor should not price the product [20]. According [15], correctly judging this perception is especially challenging for companies in the high-tech and software business. Finally, the competition serves as a benchmark to compare the prices set according to the other two variables [21].

Within these Three Cs of Pricing, concepts can be structured in cost- and valuebased models. In cost-based pricing models, price is determined by the production and delivery costs of the service. Relevant examples include flat and user-based pricing [22], [11], usage-based pricing [23,24,25,26), and performance-based pricing [27], [22], [11].

On the other hand, value-based pricing models help software vendors to set the price according to the value received by the customers, and not primarily to their willingness to pay [28], [22]. Important and widely-used forms are penetration pricing [4], [22], skimming pricing [4], [23], [29], and hybrid pricing [22], [11].

What could be noticed, due to high complexity, software vendors in the past have often adopted the "intuitive" approach: They took their development costs as a basis and then subjectively assessed the product in the market and set the price accordingly, with no objective scientific rational [17]. This is especially true for "disruptive" offerings like new BI tools, since comparables are often missing [30]. Even if such a method has been popular in the past, obviously it lacks effectiveness, and its outcomes are basically random [31].

Therefore, new pricing models had to be introduced to be less random and to better justify the gap between the cost of an additional product and the price paid by the customer. For this purpose, vendors try to examine the pricing strategy from the customer's perspective, and "assign a price that is monetary equivalent of the value the customer perceives in the product while meeting profit and return on investment goals” ([11], p.1). They are hence moving towards a customer-value-based approach 
which has the highest potential of appealing to the customers and effectively positioning the product in the market [19], [32].

Among interesting contributions to software pricing research that incorporate those ideas and approaches are the general software framework of [33], the modified cloud service version of [34] and the customer-value based pricing model of [11]. Another widely-known representative that sees this customer-value creation as the bottom of each software price setting is the strategic pricing pyramid of [30], which is based on a large scale antecedent study in different software settings (see Figure. 1).

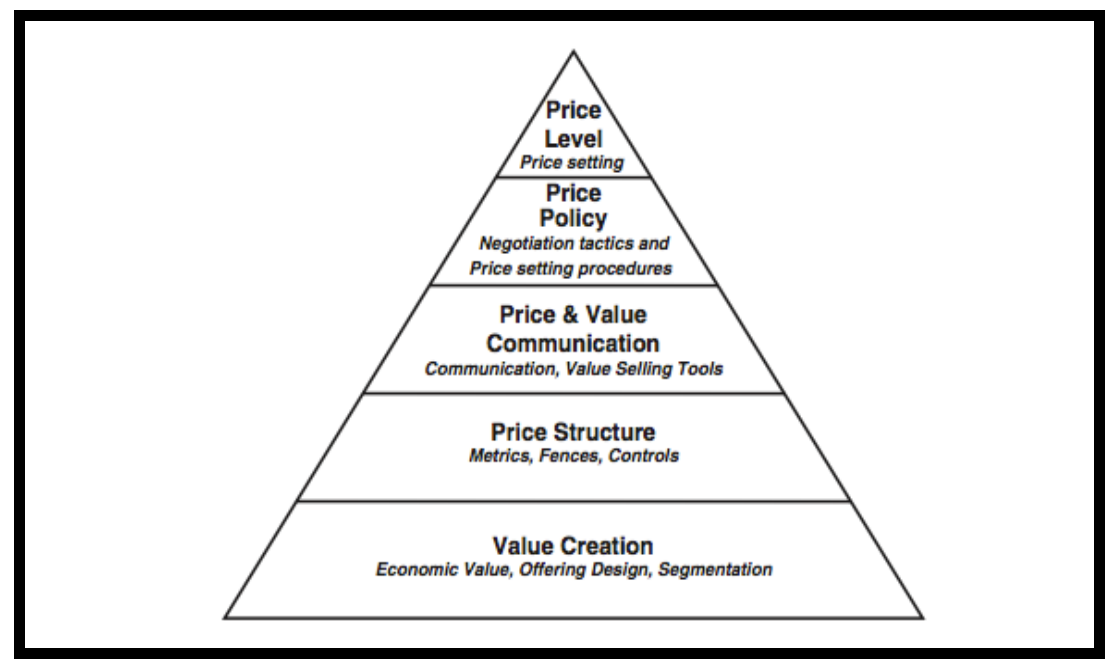

Figure 1. Strategic Pricing Pyramid [30]

Although the other drivers in this model, i.e. price structure, price \& value communication, price policy and last not least the absolute and relative price level are important as well, the basis is represented by the value creation. Value creation, i.e. the satisfaction of the users' needs, and in such a way building customer loyalty in the long-term and attracting new buyers, needs to serve as the core of price determination.

\subsection{Business Intelligence and Business Analytics}

As described previously, through gaining business advantage from data, these tools help manage information, leading executives to more informed decisions [35]. A wide array of solutions is available, and new players are constantly entering the market [36]. However, BI solutions are expensive to implement and maintain, and require powerful infrastructure. Hence, cloud computing provides the necessary IT capabilities and business agility to cut costs and achieve much needed economies of scale. SaaS solutions provide a more flexible model that aligns better with client's business objectives [37]. The possibility to have an on-demand BI solution allows companies to benefit from the services on a subscription basis, with no need for long capital requests. Even when resources would be available, BI via SaaS may still be preferable when time to market is an issue [38]. 
According to recent reports, IBM, SAP, Microstrategy, Oracle and Microsoft constitute the global top 5 BI software solution vendors $[39,40,41] .{ }^{1}$ Therefore, these companies serve as the sample for our study.

In terms of transparency of pricing, the vendors follow very diverse strategies. SAP as the global market share leader in BI\&BA does not disclose price lists whatsoever. SAP's rationale is that “... there are so many different solutions available, and they oftentimes are tailored scenarios for specific customer needs. It hasn't really made sense to publish a software price list. We want to ensure each customer or prospective customer gets product pricing that is tailored to their specific use case" (Interview with SAP's spokesman Evan Welsh, as reported by [42]. Oracle, in contrast, is wellknown for its transparency and happily publishes price lists, even though virtually no customer will ever pay these (high) prices. The other vendors fall somewhere between these extremes. Overall, many customers are resentful of their vendors' licensing practices, and need more transparency about the pricing models in general, and not only concerning the exact price. Especially with these tools often being key to the enterprises' success rather than just assuming the role of a nice-to-have functionality. That is why enterprises should treat BI software and service issues not only from a technical point of view, but also from a business perspective.

The final part of this paper is therefore going to address this problem, by suggesting a value-based pricing model that is dynamic and customizable, but at the same time transparent.

\section{Research Methodology}

In order to thoroughly analyze the pricing models applied in the BI\&BA SaaS industry, a two-phase approach has been applied: An exploratory phase that includes a literature review, qualitative expert interviews and the design of the model; and a confirmatory phase to validate the model in a dialogue with representatives of the five most important BI software vendors.

In the first phase, the available literature in the field of software pricing in BI and BA was identified and screened. For this purpose, both scientific and more practiceoriented sources have been used. In the former case, selected large-scale and reputable digital libraries in IT, engineering, business administration and related fields have been searched. In concrete terms, these sources are EBSCO Business Source Complete, the ACM Digital Library, Web of Science, IEEE Xplore, and ScienceDirect [43]. In the latter case, trade magazines, industry reports, IT/technology magazines, reviews, blogs, market research publications, and company websites have been harnessed. This was deemed necessary to also include the practitioner's view of the topic and to stay on top of developments in the fast paced software market. Search terms were comprised of a variety of queries including software pricing, pricing models and value perception in conjunction with SaaS, Cloud, and others. Based on these literature findings, interviews were carried out to get further insights into the topic. In total, nine qualitative semi-structured expert interviews [44] have been

${ }^{1}$ http://www.ibm.com; http://www.sap.com; http://www.microstrategy.com; http://www.oracle.com; http://www.microsoft.com 
conducted. Interviewees were senior software industry experts and analysts, both from consultancies and market research firms. The interviews lasted between 57 and 92 minutes, with a median of 77 minutes. After an introduction to the topic, several blocks of questions regarding the changing technological environment, the diffusion of SaaS, customer perception and satisfaction, pricing variables in relation to customers' values and importance of this value realization, among others, were asked. An interview guideline was followed that nevertheless left enough room for the interviewees to set their own emphases. The interviews were then transcribed and coded using MAXQDA 11 software. ${ }^{2}$ The literature and interview findings were then used to develop a novel conceptual software pricing model.

In the second phase, this resulting model was then discussed, validated and refined with representatives of the leading five international BI\&BA software solution providers. These representatives were contacted via email and phone and the discussions held with one executive at a time at the CeBIT 2014 in Hannover, Germany. The discussions gave a first confirmation of the validity of the model.

\section{Results and Implications}

After having analyzed the literature regarding pricing techniques applied to software products, having conducted interviews, drawn up a conceptual model and having discussed this issue with the five biggest BI software vendors, we now want to present our most important findings.

Since software pricing has become increasingly complex ("constantly changing labyrinth of pricing”, [34], p. 127), one of the most important factors for a pricing model is simplicity ("the vision is that less is more", [45], p. 7). The customers need to understand immediately how their value creation is represented in the software pricing ("Firstly, be boring. Secondly, license your software as your customers expect it be licensed - fit in with their business model", [46], p. 58). It is therefore vital to attract the customer also on a mental level, acting as a sort of partner who embraces the client's business model.

Additionally, in order to achieve an effective value co-creation it is important to have a flexible model, which reflects the client's need to iteratively address its potentially changing costs [47], [9]. In such a way, it is possible to lock in the customers offering mutually beneficial impacts, which must be clearly understood and perceived in the marketplace. The software vendor needs to leverage the SaaS cost efficiency to deliver the clients a stronger market positioning [47]. Since "users need clarity without surprise" [7], it will pay off to have an open, fair and transparent model.

The ideas from literature have then been cross-checked in the interviews. The opinion of experts working in and with the sector, who are accustomed to the requirements of companies using BI software products, reaffirmed the findings in respect to the importance of customer value realization and perception in this software sector.

\footnotetext{
${ }^{2}$ http://www.maxqda.com
} 
While of course there has not been one unison answer to the question how should the ideal customer-centric pricing model look like?, the results underpin one common theme: the model has to be customizable and flexible, in order to better represent the needs of each client. This underlines the impression that clients are not that focused on the exact price, but on the adaptability of the pricing scheme to their business model.

However, a dynamic concept that allows the client to reassess the price is not suitable for every vendor's business model. The biggest vendors in the industry deal with large multinational clients who most of the times have had the same contract for many years and do not change it regularly. Hence, they might not wish to offer the client the possibility to reassess the price after one year, since that would potentially result in a loss in revenue. However, software vendors' customer relationships are often perceived as weak, and the clients' satisfaction rate is frequently influenced negatively by causes that do not involve the qualities of the product but the complementary service. Therefore, giving the clients the possibility to reassess the price and change the variables could be a way of facing customers' dissatisfaction.

The interviews also revealed that in the future, software vendors will tend to offer a more complete product, with different functions interfaced as a whole bundle. This would mean that the biggest actors in the market continue to buy smaller companies to increase their offering and beat the competition. Thus, it will become more difficult for small software vendors to survive and remain in the market. Here again, offering the client the possibility to reassess the price of the software after one year - and communicating on this flexibility - could be an effective way for new actors in the industry to gain loyal customers and survive in the market.

What is interesting and somehow unexpected, is that there has neither been a clear preference for one particular pricing model, nor one specific technique of a valuebased pricing. Instead, software vendors should try to adapt their strategy to the client's business model. A concern that was agreed upon, however, was that such flexibility, and the investigation of the client's needs, business model and willingness to pay, require patience, time and personnel as well as financial resources.

In light of the results of the literature and empirical research, a customer-centric framework to represent the effort of software vendors to support the value creation of their clients has been designed. This serves as a conceptual model. Furthermore, it represents the role of pricing models in ensuring the clients' loyalty, which is of pivotal importance in the SaaS business model. 


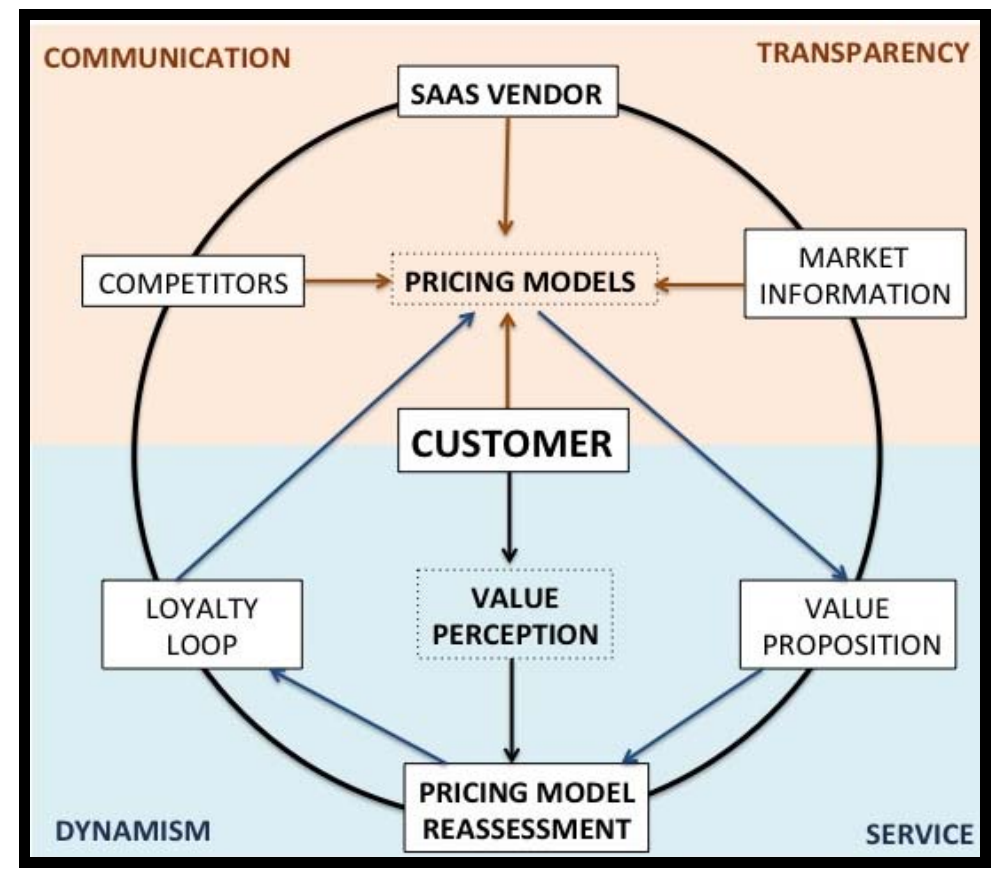

Figure 2. Customer-centered value proposition of software pricing models [own visualization]

The model develops around the customer, since it is the client who plays the most important role in a value-based pricing model. As a matter of fact, as it emerged in all the interviews, the vendor needs to truly understand the client's needs and perceptions.

The model is then divided into two phases, characterized by the two different colors in the figure. At first, the vendors need to attract the customers to their offerings, through a transparent display of the pricing model. This does not mean that the vendor has to publish the exact price of the offering online, but on the contrary share the process that leads to the price with the customer. This gives the client the opportunity to choose between pricing models based on different variables, so that the client is aware of the final result of his or her choices. However, as it emerged in the literature review (e.g. [34]), it is not realistic to suppose that the price derives only from the value realization of the client. Hence, the model depicts the different variables that lead to the price designation. These variables include primarily the client but also the competitors' offering, the specific market information (including the geographical market, the different industries and sectors that the offering is targeting), and finally the vendor itself, through the cost structure of the product.

In this way, the conceptual model displays a more harmonized pricing framework, which does not focus on the client's value only during the price designation phase, but also and most importantly in the subsequent stage. Finally, the first stage also includes communication, a keyword that previous pricing models have ignored completely. This empirical research has confirmed that communicating the pricing model is essential in value-based pricing models since the value realization often does not take 
place solely due to a lack of clients' understanding. It is a concept that needs to be directly linked to pricing techniques.

The second phase of the conceptual model illustrates the post-purchase stage, which is focused on two other key words, service and dynamism.

The first concept is self-explanatory, since SaaS involve the offering of a service instead of a product. However, through the interviews and discussions with the top five BI vendors, it became apparent how important it is for the vendor to offer a full service. This full service is not only limited to the functioning of the software itself, but also encompasses guidance of the customer and a focus on relationship management.

The client has chosen the software because of the value proposition of the vendor. However, the conceptual model also illustrates the follow-up of this proposition, with the value perception that is essential to reassess the price in collaboration with the vendor. As it repeatedly emerged in the interviews, the customers usually value the trial period as an essential tool to understand the product, and to decide whether it meets the needs of their businesses.

Within the model, the same concept of a trial is included, but applied to the afterpurchase phase. Hence, the client has a period of time to see whether the variables he has chosen as a fundament for the price of the service are the ones that best depict his or her business and best represent the value realization. In this way, the clients can then reassess the price according to their business model needs, through a pricing concept that is dynamic and allows for alterations. In contrast with previous pricing models, the dynamism here concentrates on the client's needs and not on the vendor's strategy (as in the traditional value-based pricing models, namely penetration pricing and skimming pricing).

The reassessment of the price aims to shift the client's investigation from an exante to an ex-post stage. As a matter of fact, the vendor needs to keep a good relationship with the client, with a frequent exchange of information, and through this dialogue the vendor can save resources, time and money from investigating the client's needs before reaching him.

Finally, in the model, this leads to a loyalty loop, as in McKinsey's consumer decision journey model [48]. Since the clients see their needs fulfilled, and the value exploited, they do not seek other software vendors and remain loyal to the service offered. This is important in light of recent research publications, which have been analyzed in the previous chapters. They revealed that customers in the majority of cases show a low level of client satisfaction, and are not pleased with the vendor relationship vendors [39,40,41].

Hence, it can be seen as crucial to switch to and constantly strive for a customercentered value proposition.

\section{Conclusion}

After the software revolution and the introduction of Software as a Service (SaaS), the end customer has become essential in the definition of the overall strategy of a software vendor. Therefore, the client's needs and expectations have to be reflected in the Business Intelligence \& Business Analytics (BI\&BA) software supplier's pricing 
strategy even more. Our research aim therefore was to develop a customer-centric conceptual model for the pricing of SaaS BI\&BA software. To reach this goal, a thorough literature study both in scientific and practice-oriented publications has been conducted, followed by a round of nine semi-structured expert interviews. With this data pool, a conceptual model that consolidates and compresses prior models has been developed. To validate this conceptual model, we discussed it with representatives of the five leading BI\&BA software vendors.

In the course of the study it became clear that each software pricing model has its own unique strengths and weaknesses; each customer achieves value in a different way. Therefore, taken together, the conceptual model developed here caters to these two aspects and is intended to show the need for flexibility and scalability on behalf of the software vendor, in order to meet the clients' expectations.

We think the contribution of this research is twofold:

First, in the scientific community, there is very little pricing research in the particular but important case of Business Intelligence software. Here, the conceptual model can help stimulating the discussion immediately in order to ignite further necessary research. It may contribute to focus more on the value-perception and the interaction between customer and vendor, and less on technical issues, which have already been thoroughly researched.

Second, the findings and the model can help practitioners in rethinking their pricing method. Higher market pressure and increased competition in this field of the software industry make customer satisfaction and loyalty ever more important. Thus, having a strategic and customer-centric look on the current pricing practice can lead to lower customer churn rates, higher customer satisfaction and more pricing flexibility.

However, our study also contains a number of limitations: On the one hand, the research has been conducted without investigating the technical characteristics of the software products under examination. This would have allowed a deeper understanding of the cost structure, and hence the possible pricing techniques to apply. On the other hand, the findings have only been discussed with the five biggest BI\&BA software vendors and small-and mid-sized companies have been ignored. As this particular share of the software market is very dynamic, partly due to constant start-up activity, a generalization of the findings may be problematic at this point of time of our research.

Future research may address these shortcomings and should potentially also take into account the well-described vendor/client lock-in effects of SaaS applications which frequently occur. In addition, the conceptual model is just a starting-point to initiate more research in terms of putting the client center-stage when it comes to value delivery, value communication and value pricing in the software and BI\&BA industry.

\section{References}

1. The Economist: Universal Service? Proponents of "software as a service" say it will wipe out traditional software. April 20 (2006)

2. Carraro, G., Chong, F.: Software as a service (SaaS): An enterprise perspective. Microsoft Corporation (2006) http://msdn.microsoft.com/en-us/library/aa905332.aspx 
3. Gruman, G., Morrisson, A., Retter, T.: Software Pricing Trends: How vendors can capitalize on the shift to new revenue models. PriceWaterhouseCoopers (2007) http://www.pwc.com/en_us/us/technology-innovation-center/assets/softwarepricing_x.pdf

4. Rohitratana, J., Altmann, J.: Impact of pricing schemes on a market for software as a service and perpetual services. Future Generation Computer Systems, 28(8), 1328-1359 (2012)

5. Bertini, M., Wathieu, L.: How to stop customers from fixating on price. Harvard Business Review, 85-91 (2010)

6. Bontis, N., Chung, H.: The evolution of software pricing: from box licenses to application service provider models. Internet Research: Electronic Networking Applications and Policy, 10(3), 246-255 (2000)

7. Schneider, S.: The dirty little secret of software pricing. RTI Whitepaper (2012) http://www.rti.com/whitepapers/Dirty_Little_Secret.pdf

8. Baker, W.: Software license and maintenance pricing principles - Best practices and case studies. Soft Summit Conference, Santa Clara, CA (2004) http://www.softsummit.com/library/presentations/2006/HomayounHatami_McKinseyandC ompany.pdf

9. Lehmann, S., Buxmann, P.: Pricing strategies of software vendors. Business \& Information Systems Engineering 6, 452-462 (2009)

10. Heffron, P.: Understanding Software Pricing Models. Esna Technologies (2013) http://ease.esna.com/Sys/Document/Open/7Ot000000000031000a

11. Harmon, R., Demirkan, H., Hefley, B., Auseklis, N.: Pricing strategies for information technology services: a value-based approach. In: 42nd Hawaii International Conference on System Sciences. IEEE Press, New York (2009)

12. Choudhary, V.: Software as a service: Implications for investment in software development. In: 40th Hawaii International Conference on System Sciences. IEEE Press, New York (2007)

13. Swoyer, S.: Analytics in the cloud. The Challenges and Benefits. TDWI (2013) http://tdwi.org/research/2013/11/tdwi-ebook-analytics-in-the-cloud-the-challenges-andbenefits.aspx

14. Van Der Lans, R.: Data Virtualization for Business Intelligence Systems: Revolutionizing Data Integration for Data Warehouses. The Morgan Kaufmann Series on Business Intelligence. Morgan Kauffman, Waltham (2012)

15. Mohr, J., Sengupta, S., Slater, S.: Marketing of High-Technology Products and Innovations. Pearson Education, New Jersey (2005)

16. Churakova, I., Mikhramova, R.: Software as a Service: Study and Analysis of SaaS Business Model and Innovation Ecosystems (2010) http://lib.ugent.be/fulltxt/RUG01/001/459/665/RUG01-001459665_2011_0001_AC.pdf

17. O’Connor, S.: How indigenous software companies price their product and service offerings: An exploratory investigation (2009) http://repository.wit.ie/1453/1/How_indigenous_software_companies_price_their_product _and_service_offerings_an_exploratory_investigation.pdf

18. Ojala, A., Tyrvainen, P.: Business models and market entry mode choice of small software firms. Journal of International Entrepreneurship 4, 60-81 (2006)

19. Desisto, R., Paquet, R.: Learn the Economic Advantages of a Pure SaaS Vendor. Gartner (2007) https://www.gartner.com/doc/537208/learn-economic-advantages-pure-saas

20. Marn, M., Roegner, E., Zawada, C.: Pricing new products. McKinsey Quarterly 3(XXX), 40-49 (2003) 
21. Shipley, D., Jobber, D.: Integrative pricing via the pricing wheel. Industrial Marketing Management 30, 301-14 (2001)

22. Harmon, R., Raffo, D., Faulk, S.: Value-based pricing for new software products: Strategy insights for developers. In: Portland International Conference on the Management of Engineering and Technology, IEEE Press, New York (2004)

23. Singh, J.: Software Pricing Strategies http://www.slideshare.net/Alistercrowe/software-pricing-strategies

24. Ojala, A.: Comparison of different revenue models in SaaS. In: Prakash, E. (ed.) Proceedings of 5th Computer Games, Multimedia \& Allied Technology Conference, pp. 120-123 (2012)

25. Waters, B.: Software as a service: A look at the customer benefits. Journal of Digital Asset Management 1, 32-39 (2005)

26. Choudhary, V., Tomak, K., Chaturvedi, A.: Economic Benefits of Software Renting. Journal of Organizational Computing and Electronic Commerce 8, 4, 277-305 (1998)

27. Keranen, T.: Value based pricing of ICT services at Citiusnet Ltd. (2010) http://publications.theseus.fi/handle/10024/17291

28. Monroe, K.: Pricing: Making Profitable Decisions. McGraw-Hill/Irwin, New York (2002)

29. Monroe, K.: Buyers' Subjective Perceptions of Price. Journal of Marketing Research 10, 70-80 (1973)

30. Kittlaus, H. B., Clough, P. N.: Software Product Management and Pricing: Key Success Factors for Software Organizations. Springer, Berlin/Heidelberg (2009)

31. Hinterhuber, A.: Customer value-based pricing strategies: Why companies resist. Journal of Business Strategy 29, 4, 41-50 (2008)

32. Cavusgil, S. T.: Pricing for global markets. Columbia Journal for World Business 31, 4, 66-78 (1986)

33. Iveroth, E., Westelius, A., Petri, C.-J., Olve, N.-G., Coster, M., Nilsson, F.: How to differentiate by price: Proposal for a five-dimensional model. European Management Journal, 109-123 (2012)

34. Laatikainen, G., Ojala, O., Mazhelis, O.: Cloud Services Pricing Models. In: Herxwurm, G., Margaria, T. (eds.): Software Business, from physical products to software services, 4th International Conference, ICSOB 2013, pp. 117-129. Springer, Berlin/Heidelberg (2013)

35. Muntean, M., Muntean, C.: Evaluating a Business Intelligence Solution. Feasibility Analysis Based On Monte Carlo Method, ECECSR Journal 2, 85-102 (2013)

36. Baur A. W., Breitsprecher M., Bick M.: Catching Fire: Start-Ups in the Text Analytics Software Industry. In: Americas Conference on Information Systems (AMCIS), Savannah, August (2014)

37. Thompson, W., Van der Walt, J.: Business Intelligence in the cloud. SA Journal of Information Management 12, 1 (2010)

38. Mitchell, R.: Is SaaS a good fit for BI?. Computerworld, pp. 22-25, 22 February (2010)

39. Schlegel, K., Sallam, R., Yuen, D., Tapadinhas, Y.: Magic Quadrant for Business Intelligence and analytics platforms. Gartner (2013) http://www.gartner.com/technology/reprints.do?id=1-1DZLPEP\&ct=130207\&st=sb

40. Business-Software Report: Top 10 Business Intelligence Software Report, Comparison of the leading Business Intelligence Software Vendors. Business-Software (2013) http://c3330831.r31.cf0.rackcdn.com/top_10_bi.pdf

41. Dresner, H.: Wisdom of crowds embedded intelligence market study. Dresner Advisory Services (2013) http://www.dundas.com/wisdom-of-crowds-embedded-bi-study

42. Wailgum, T.: Why doesn't SAP publish its price list? ASUG News (2011) http://www.asugnews.com/article/why-doesnt-sap-publish-its-price-list 
43. Chen, H., Chiang, R. H. L., Storey, V. C.: Business Intelligence and Analytics: From Big Data to Big Impact. MIS Quarterly 36, 4, 1165-1188 (2012)

44. Hair, J. F., Celsi, M. W., Money, A. H., Samouel, P., Page, M. J.: Essentials of Business Research Methods, second edition. M. E. Sharpe, Armonk/NY (2011)

45. Luoma, E.: Examining Business Models of Software-as-a-Service Firms. In: Altmann, J., Vanmechelen, K., Rana, O. (eds.): Economics of Grids, Clouds, Systems, and Services. GECON 2013, pp. 1-15. Springer, Heidelberg (2013)

46. Davidson, N.: Don't just roll the dice - A useful short guide to software pricing. Simple Talk Publishing (2009)

47. Kauffman, R. J., Ma, D.: Cost Efficiency Strategy in the Software-as-a-Service Market: Modeling Results and Related Implementation Issues. In: Altmann, J., Vanmechelen, K., Rana, O. (eds.): Economics of Grids, Clouds, Systems, and Services. GECON 2013, pp. 16-28. Springer, Heidelberg (2013)

48. Court, D., Elzinga, D., Mulder, S., Vetvik, O. J.: The consumer decision journey. McKinsey Quarterly (2009)

http://www.mckinsey.com/insights/marketing_sales/the_consumer_decision_journey 